\title{
Injected and Colouring Substances Largely Used in Processing Microscopic Anatomical Structures
}

\author{
SORIN LUCIAN BOLINTINEANU1", DANIELA ANCA PUSCASIU2\#, CODRUTA ILEANA PETRESCU1\#, ROMULUS FABIAN TATU3", \\ ELENA POP', CARMEN SOFICA TATU**, ALINA MARIA SISU ${ }^{1}$ \\ ${ }^{1}$ Victor Babes University of Medicine and Pharmacy Timisoara, Department of Anatomy and Embryology, \\ 2 Eftimie Murgu Sq., 300041, Timisoara, Romania \\ 2Victor Babes University of Medicine and Pharmacy Timisoara, Department of Microscopic Morphology, Discipline of Molecular \\ and Cellular Biology, 2 Eftimie Murgu Sq., 300041, Timisoara, Romania \\ ${ }^{3}$ Victor Babes University of Medicine and Pharmacy Timisoara, Department of Ortopaedics-Traumatology-Urology and Imagistic, \\ Discipline of Ortopaedics-Traumatology III, 2 Eftimie Murgu Sq., 300041, Timisoara, Romania \\ ${ }^{4}$ Victor Babes University of Medicine and Pharmacy Timisoara, Department of Functional Science, Discipline of Physiology, 2 \\ Eftimie Murgu Sq., 300041, Timisoara, Romania
}

There are many fixing and colouring substances largely used in the anatomy laboratories, for teaching purpose. We have injected 22 adult human hearts, removed from the cadavers belonging to the Anatomy and Embryology Department. On 6 specimens we have followed the embryologic myocardium structures for micro angio architecture studies. We used histological techniques like: haematoxylin-eosin, Van Gieson, and Masson's Trichrome methods. Also we have removed and dissected 14 kidneys and 16 anatomical structures of the peripheral nervous system: coeliac ganglia, aortico renal ganglia and mesenteric ganglia. The least were analyzed using specific techniques of the nervous system: Nissl method and Bielschowsky silver stain method. 8 foetuses (aged between 4 and 8 months of gestation) were dissected and also analysed. Our results were in according to the literature studies.

Keywords: staining methods, anatomical specimens, ganglia, fixation

Microscopic anatomy deals with the very small specimens of human body. For a better preservation, some steps must be followed: dissection of the viscus, fixation, slicing and colouring. There are two important steps: fixation and colouring. Fixation involves substances with special chemical properties, related to proteins amine group, stopping the decay and preserving the tissue shape and structure. Colouring is the last step; highlights the cells and fundamental substance. Special colourings reveal nucleus chromatin, elastic fibres, conjunctive fibres, reticulin, and fat deposits.

Fixing solution properties mustbe: killing faster the cells, penetrating the tissue, keeping natural the structures, keeping smooth the structures. Such substances are: formalin, Bouin solution. Proper cadaver enzymes destroy the tissue (autolysis), butthis process is stopped by fixation, so as faster the fixing solution acts on the tissue, as faster the structures remain intact. Fixing solutions having great power of dispersion are suitable for the preservation techniques: acetone, alcohol and acetone, ethylic alcohol acetic acid, chloroform, methyl alcohol. Some of them like alcohol and chloroform destroy the lipids, others the carbohydrates. The shrinkage of the tissues reaches $40 \%$ of the primary volume after alcohol fixation and paraffin inclusion. Using Bouin solution, final shrinkage is up to $1 \%$. Diluted formalin swollen tissue until $5 \%$ and then shrinks it up to $20 \%$ [1].

The formalin is used largely in the anatomy laboratories, but its harmful action on teguments and mucosae avoids its using on large scale. Smaller sections are embedded in formalin $(4-6 \mu)$, leading to a careful and accurate examination of the structure. This procedure allows one single row of cells examination, but the disadvantage is the long period for inclusion, in order to avoid deformations. For this reason progressive ethylic alcohol solutions are used, from 70 degrees to 96 degrees, the last treatment is with absolute alcohol, allowing the removal of all the tissue water. The last partis paraffin and chloroform (equal parts) inclusion and/or then only double paraffin inclusion (2- 24 $h$ in total) [2,3].The glycerine is considered good preservative, with maintaining appearance, consistency and viewing structures, with no odour, easy handling and exposure of the parts in an anatomy lab. Another benefit to the glycerine use is the possibility of exposure of the outside part of any solution, which facilitates the work, reduces health hazards for those working daily with anatomical specimens [4].

\section{Experimental part \\ Material and methods}

For teaching purpose, we have injected 22 adult human hearts, removed from the cadavers belonging to the Anatomy and Embryology. The hearts were injected via Valsalva aortic sinuses, using needle syringe $25 \mathrm{~mL}$ of black ink, for the left coronary artery we have injected both, circumflex artery and left anterior descending artery with equal quantities. After that the samples were fixed in formalin. On 6 specimens we have followed the embryologic myocardium structures for micro angio architecture studies. We used histological techniques like: haematoxylin-eosin, Van Gieson, and Masson's Trichrome methods.

Also we have removed and dissected 14 kidneys and 16 anatomical structures of the peripheral nervous system: coeliac ganglia, aortico renal ganglia and mesenteric ganglia. The least were analyzed using specific techniques of the nervous system: Nissl method and Bielschowsky silver stain method. 8 foetuses (aged between 4 and 8 months of gestation) were dissected and also analysed. Specimens were conducted in accordance with the 
Romanian law / procedural norms for medical legal expertises No. 1134/C/25/05.2000 (Ministry of J ustice), and 255/4.4.2000 of the Health Ministry, Art. 42/ ethics of autopsy practice.

\section{Results and discussions}

Our studies have focused both on the identification of microscopic structures in adult anatomical preparations and in ontogenesis.There have been used vital and supra vital colouring substances. A vital colouring is an accumulation of the colloid particles in cells cytoplasm, especially in the reticulo histiocitary system cells. A supra vital colouring is an accumulation of electropositive colouring substances in the cytoplasm organelles. We have introduced the vital colouring substance by intravenous way, subcutaneous or intraperitoneal. Injected quantity must be dosed very well because there is a supra colouring risk (higher when intravenous way is used). Fixation and conservation techniques are necessary to stop the autolysis. Conservation preserves this state of fixation. Common fixation techniques are perfusion, injection, and immersion (Romeis, 1989). Fixation techniques involve formaldehyde, ethanol, or propanol (Wilcke et al., 1987). Phenol, formerly used for anatomical conservation, was abolished due to its toxic, skin-irritating, and possibly mutagenic effects (Murray et al., 2007) and was replaced by formaldehyde; even the last one is also toxic.

\section{Haematoxylin-eosin method}

Haematoxylin and eosin (H\&E) stains have been used for decades and are still essential for recognizing various tissue types. The stain has been unchanged for many years because it works well with a variety of fixatives and displays a broad range of cytoplasm, nuclear and extracellular matrix features [5,6]. Haematoxylin has a deep blue-purple colour and stains nucleic acids by a complex, incompletely understood reaction. A disadvantage of haematoxylin staining is that it is incompatible with immunofluorescence. It is the fastest laboratory colouring method. Eosin colouring takes 1-2 min, distillate water 1-2 min and xylol: 2-3 min [7-9, 45]. On the formalized kidneys we have performed $H \& E$ staining, highlighting the glomeruli and arterial vessels. Other authors also used in their studies the same staining, but with time reducing and no such satisfactory results [10] (fig.1).

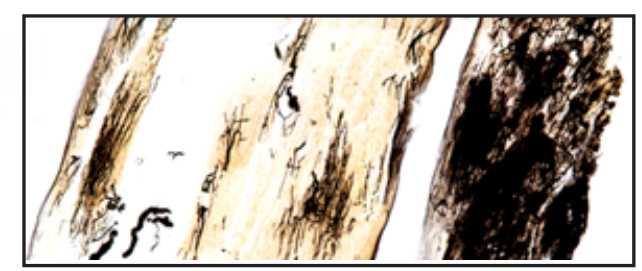

Fig. 1. Left ventricle septal wall, human adult specimen, Black ink method, X40

\section{Masson's Trichrome Stain}

Masson's Trichrome Stain requires the following steps: Lugol solution and natrium hyposulfite if there was a previous fixation in the sublimate solution; Weigert ferum haematoxylin (10 min ); lithium carbonate 1 minute; fuxin acid $+4 \mathrm{~cm}^{3}$ acetic acid $+300 \mathrm{~cm}^{3}$ distillate water 15 min; finally $1 \%$ distillate water and molybdic acid for $4 \mathrm{~min}$ [11-15] (fig. 2).

\section{Van-Gieson's Stain}

It can be used any universal fixation substance. The slices are immersed 5-10 min in Weigert ferum haematoxylin, then 3-4 min under tap water. The second

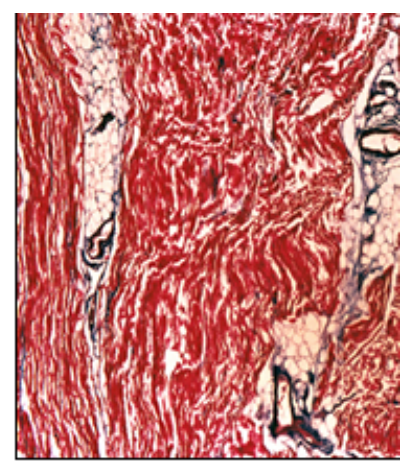

Fig.2. Interventricular wall of the heart - micro arteries contained in the embryonic myocardium, Masson's Trichrome Stain, 10x

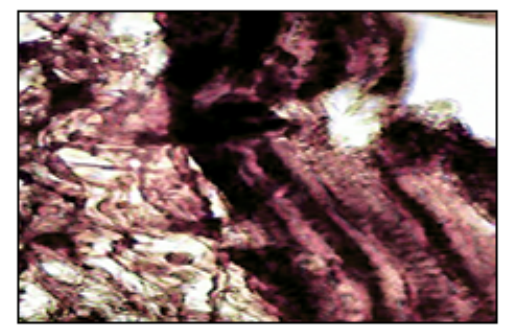

Fig.3. Coeliac ganglion, 4 month- human foetus. Bielschowsky silver staining. 400x; coeliac neuroblasts are seen

step is saturated solution of lithium carbonate until dark blue colouring. Finally, the specimens are immersed in picrofuxin solution. For micro vascular microscopic study on sinuatrial node pathway we have used human adult specimens, either intra coronary black ink injected, either using haematoxylin-eosin, Masson's Trichrome Stain and Van Gieson Method [16-22].

Clinical studies made by some authors showed the importance of the reperfusion areas [23-26,46,47]. They have showed a major importance of knowing the heart structures micro vasularization: moderator band, papillary muscles, and embryonic miocardium. The main threatening is myocardial necrosis and the reperfusion type possibility [27-30]. Haupt et al. (1983) discussed the flowing possibility through a collateral artery, left anterior descending artery and through the moderator band, when a right proximal coronary artery occlusion occurs [31,32]. Kawashima et al. (2003), Berdajs et al. (2003), and Bernanke et al. (2002) [33-35] studied the structure and ultrastructure of the moderator band capillaries on foetal and adult specimens. They consider trabecula septomarginalis formed by proper myocardium and a very thin Purkinje cells fascicle peripheral disposed. Cardiac microvascular bed is essential for cardiac pump role. In the heart there is a coronary perfusion increasing, that leads to the oxygen consumption augmentation and the contraction force. Left papillary muscles are important in this pump role [36-38]. The number of papillary muscles is individual variable, could be double ( $74 \%$ of cases) or unique $(61 \%)$ [ 39 - 42].

\section{Histological techniques for nervous tissue samples}

Histological techniques for nervous system elements identify: nervous cell, its prolongations, myelin sheath, nervous fibres, glial tissue. Firstly, a fixation is necessary. The most used is formalin $10 \%$, then mix of ammonium bromide and formalin; ethylic alcohol; potassium bichrome. Because the nervous system is rich in fat, inclusion technique leads to shrinkage. Neurofibrils are studied using impregnation techniques.

\section{Niss/ Method}

Original Nissl method requires alcohol 96 degrees fixation. We have used a modified variant of this method, which can be applied even on the structures fixated in formalin. The results from our study were satisfactory. Slides colouring with toluidine blue $0.1 \%, 12-15 \mathrm{~h}$. Next 


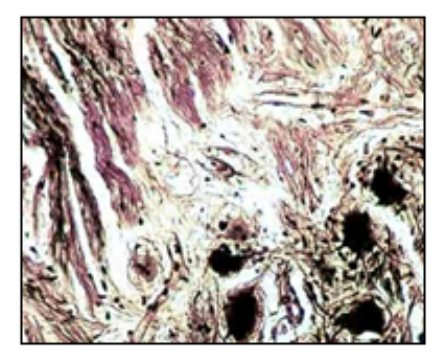

Fig. 4. Adult coeliac ganglion; Coeliac ganglion neurons; well represented dendrite network. Bielschowsky silver staining, 200x

step was embedded in distillate water and a saturated solution of lithium carbonate diluted 10 times. This method is used for the detection of Nissl body in the cytoplasm of neurons on para formaldehyde or formalin-fixed, paraffin embedded tissue sections.

\section{Bielschowsky Method}

Max Bielschowsky improved this method by incubating formalin-fixed frozen sections in the silver nitrate prior to the ammoniac silver solution [43].

We have used specimens from recently dead bodies fixated in formalin solution 20\%, $3-4 \mathrm{~mm}, 5-6$ days; samples are washed with tap water several hours and distillate water $2 \mathrm{~h}$. Then, silver nitrate $2 \%$ solution is used for 3 - 5 days in the obscure chamber. A short washing in bi distillate water and ammonium silver solution is performed: in an Ehrlenmeyer bottle are mixed $10 \mathrm{~cm}^{3}$ from silver nitrate $10 \%$ solution in bi distillate water. Over this, $10 \mathrm{~cm}^{3}$ of aqueous solution of natrium hydroxide is added. The result was a silver oxide precipitate. A rinse in distillate water and a formalin $20 \%$ reducing during $12-24$ $\mathrm{h}$ is performed. The slices were immersed in a solution formed of: 5 drops of gold chloride solution $1 \%+10 \mathrm{~cm}^{3}$ distillate water +2 - 3 drops of glacial acetic acid.

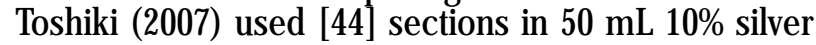
nitrate in dark at $37^{\circ} \mathrm{C}$ for $30 \mathrm{~min}$. 1. He washed sections in $0.1 \%$ ammonium hydroxide $3 \mathrm{X}$ for $2 \mathrm{~min}$ at room temperature. Then, he added $350 \mu \mathrm{L}$ developer solution

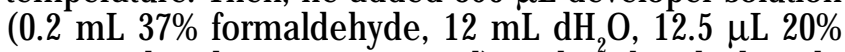
nitric acid and $0.05 \mathrm{~g}$ citric acid) to the silver hydroxide solution. He washed in $0.1 \%$ ammonium hydroxide $3 X$ for 2 min and $\mathrm{dH}_{2} \mathrm{O}_{2} \mathrm{X}$ for $2 \mathrm{~min}$ and toned in $0.2 \%$ gold chloride for 5 min. Finally, he fixed it in $5 \%$ sodium thiosulfate for 1 min. Other modified staining methods have been used during time [42] (figs. 3,4)

Dendritic morphologic evolution and neuronal specialization are highlighted by this method.

Table 1

DIFFERENT STAINING METHODS USED IN LABORATORIES

\begin{tabular}{|c|c|c|c|c|}
\hline No. & $\begin{array}{l}\text { Staining } \\
\text { Method }\end{array}$ & Structure & Appearance & Disadvantage \\
\hline 1. & $H \& E$ & nuclei & stained blue & $\begin{array}{l}\text { Incompatible with } \\
\text { immunofluorescence }\end{array}$ \\
\hline 2. & $\mathrm{H} \& \mathrm{E}$ & $\begin{array}{l}\text { cytoplasm and extracellular } \\
\text { matrix }\end{array}$ & degrees of pink & $\begin{array}{l}\text { Incompatible with } \\
\text { immunofluorescence }\end{array}$ \\
\hline 3. & $\mathrm{H} \& \mathrm{E}$ & Nuclei & $\begin{array}{l}\text { heterochromatin } \\
\text { condensation }\end{array}$ & $\begin{array}{l}\text { Incompatible with } \\
\text { immunofluorescence }\end{array}$ \\
\hline 4. & $\mathrm{H} \& \mathrm{E}$ & Nucleoli & blue cast & $\begin{array}{l}\text { Incompatible with } \\
\text { immunofluorescence }\end{array}$ \\
\hline 5. & $\mathrm{H} \& \mathrm{E}$ & Golgi zone & $\begin{array}{l}\text { Absence of staining in } \\
\text { a region next to the } \\
\text { nucleus }\end{array}$ & $\begin{array}{l}\text { Incompatible with } \\
\text { immunofluorescence }\end{array}$ \\
\hline 6. & $\begin{array}{l}\text { Masson's } \\
\text { Trichrome }\end{array}$ & Nuclei, muscle & red & None \\
\hline 7. & $\begin{array}{l}\text { Masson's } \\
\text { Trichrome }\end{array}$ & Nucleoli & black & None \\
\hline 8. & $\begin{array}{l}\text { Masson's } \\
\text { Trichrome }\end{array}$ & Cytoplasm, amyloid & Pink-purple & None \\
\hline 9. & $\begin{array}{l}\text { Masson's } \\
\text { Trichrome }\end{array}$ & Erythrocytes & Orange & None \\
\hline 10. & $\begin{array}{l}\text { Masson's } \\
\text { Trichrome }\end{array}$ & Conjunctive tissue, mucus & blue & None \\
\hline 11. & Van-Gieson's & Collagen & Red & None \\
\hline 12. & Van-Gieson's & Smooth and striated muscle & $\begin{array}{l}\text { Yellowish } \\
\text { brownish }\end{array}$ & None \\
\hline 13. & Van-Gieson's & $\begin{array}{l}\text { Cornified epithelium, Hyalin, } \\
\text { Cytoplasm }\end{array}$ & Yellow & None \\
\hline 14. & Van-Gieson's & Nuclei & Blue to Black & None \\
\hline 15. & Van-Gieson's & Erythrocytes & Gold & None \\
\hline 16. & Niss1 & Neurons & purple-blue grains & Long time \\
\hline 17. & Niss1 & Nucleolus, nuclear membrane & Intense coloured & Long time \\
\hline 18. & $\begin{array}{l}\text { Bielschowsky } \\
\text { silver }\end{array}$ & Neurofibrils & black & Only nervous tissue \\
\hline 19. & $\begin{array}{l}\text { Bielschowsky } \\
\text { silver }\end{array}$ & Conjunctiv tissue & Yellow-grey & Only nervous tissue \\
\hline
\end{tabular}




\section{Conclusions}

Special colourings reveal nucleus chromatin, elastic fibres, conjunctive fibres, reticulin, and fat deposits.

Histological techniques for nervous system elements identify: nervous cell, its prolongations, myelin sheath, nervous fibres, glial tissue.

Bielschowsky's silver stain is a very useful tool to detect nerve fibres. Itcan be used to stain axons, neurofibrils and senile plaques in the central nervous system. This method is easy to perform in clinic (Alzheimer's disease).

As teaching purpose, these methods are very useful in the anatomy field.

Acknowledgement: Present study was supported by funds kindly provided by Victor Babes University of Medicine and Pharmacy Timisoara, Romania, through P-III-C5-PCFI-2017/2018-03 Internal grantacronym UROVESSELS.

\section{References}

1.GROSCURTH P., P. EGGLI, J. KAPFHAMMER, G. RAGEr, J.-P. HORNUNG, and J.D.H. FASEL, Gross Anatomy in the Surgical Curriculum in Switzerland: Improved Cadaver Preservation, Anatomical Models, and Course Development, The AnatRec (New Anat.) 265:254256, 2001.

2.MANNER J, PEREZ-POMARES JM, MACIAS D, MUNOZ-CHAPULI R. The origin, formation and developmental significance of the epicardium: a rev. Cel Tiss Org. 2001;169:89-103.

3.HAMMER N, LO"FFLER S, FEJA C, et al, Ethanol-Glycerin Fixation with Thymol Conservation: A Potential Alternative to Formaldehyde and Phenol Embalming, Anat Sci Educ 5: 225-233, 2012.

4.SILVA, NA., GALVAO, APO., FRAGA, KB., et al., Comparative study between tw 0 techniques using a glycerin in the conservation of central nervous system, J. Morphol. Sci., 2011, 28, 4,280-282.

5.FISCHER AH, J ACOBSON KA, ROSE J, ZELLER R.; Hematoxylin and eosin staining of tissue and cell sections. CSH Protoc. 2008 May 1;2008:pdb.prot4986. doi: 10.1101/pdb.prot4986.

6.TATU RF, ANUSCA DN, GROZA S, MARUSCIAC L, BOJ IN FM, TATU C, HURMUZ M, PÃUNESCU V, Morphological and functional characterization of femoral head drilling-derived mesenchymal stem cells, Rom J Morph Embryo 2014,55(4):1415-1422.

7.CARDIFF RD., MILLER CH., ROBERT J., Manual Hematoxylin and Eosin Staining of Mouse Tissue Sections, Munn Cold Spring Harb Protoc; 2014; doi:10.1101/pdb.prot073411.

8.TATU, R.F, IVASCHESCU HURMUZ, V., M., TATU, C, PUSCASIU, D., SISU, A.,Vibration Behaviour of Bone Fractures Fixed with Biocompatible Material Plates, Mat Plast, 50, no. 4, 2013, p. 269 9.TATU, R.F., MARSAVINA, L, VOICONI, T., HURMUZ, M., TATU, C., UNGUREAN, C, ROSU, S., Reinforcement of Tibial Fixation in Anterior Cruciate Ligament, Reconstruction Using a Polyester Multi Stranded Long Chain Polyethylene Core Suture Material, Mat Plast, 51, no.4, 2014, p. 460

10.PUSCSIU D, TATU C, TATU RF, POTENCZE, POPESCU R, MUNTEAN I, VERDES $D$, The significance of angiogenesis and tumoral proliferation in renal cell carcinoma, Rom J Morphol Embryol, 2011;52(1 Suppl): 369-372.

11.COHEN A. H.,M.D Masson's Trichrome Stain in the Evaluation of Renal Biopsies An Appraisal. A.J.C.P.-Vol.65.

12.CLARK, G., (ed) Staining Procedures, 3rd Ed., William \& Wilkins Co., Baltimore, C 1973, 50.

13.PETRE, I., BERNAD, E., CRAINA ,M., CITU, C., BOLINTINEANU, S., POP, E., STOIAN, D., SIPOS, S., LUNGEANU, D., FURAU, C., FURAU, G., PANTEA, S., IONITA, I., Determining Markers PIGF, sFIt1 and the Ratio sFIt1/PIGF- Prognostic Tool in Patients with Preeclampsia, Rev. Chim.(Bucharest), 67, no. 11, 2016, p. 2365

14.Van GIESON, I., New York Med. J., 1889, 50:57-60.

15.MALLORY, F.B., Pathological Technique, Hafner Publishing., New York, 1961, p 152.

16.REESE DE, MIKAWA T, BADER DM. Development of the coronary vessel system. Circ Res 2002;91:761-768.
17.REIG J , ALBERTI N, PETIT M. Arterial vascularization of the human moderator band: an analysis of this structure's role as a collateral circulation route. Clin Anat. 2000;13(4):244-250.

18.SANCHEZ-QUINTANA D, CABRERA JA, FARRE J, CLIMENT V, ANDERSON RH, HO SY -Sinus node revisited in the era of electroanatomical mapping and catheter ablation, Heart, 2005 91:189194.

19.PEREZ-POMARES JM, CARMONA R, GONZALEZ-IRIARTE M, et al., Origin of coronary endothelial cells from epicardial mesothelium in avian embryos. Int J Dev Biol. 2002;46:1005-1013.

20.LOUKAS M, CURRY B, BOWERS $M$, et al, The relationship of myocardial bridges to coronary artery dominance in the adult human heart. J Anat. 2006;209(1):43-50.

21. KINGSLEY K, RUST WL, HUFF JL, SMITH RC, PLOPPER GE. , PDGF-BB enhances expression of, and reduces adhesion to, laminin5 in vascular smooth muscle cells. Biochem Biophys Res Commun. 2002;294:1017-1022.

22.ABUIN G, NIEPONICE A, MARTINEZ S, FERNANDO C. The role of atrial vessels in aortic root and mitral valve operations. Ann Thorac Surg 2000;70:1234-1237.

23.HAUPT HM, HUTCHINS GM, MOORE GW. Right ventricular infarction: role of the moderator band artery in determining infarct size. Circulation. 1983 J un; 67(6):1268-72.2.

24.IONITA, I., GRIGORITA, L., BACEAN MILOICOV, C., PETRE, I., BERNAD, E.,CRAINA, M., DIACONU, M., CITU, C., RADU, F., OROS, D., BOGLUT, A., FURAU, G., ENATESCU, V., The Role of Thrombophilia in Pregnancy, Rev. Chim.(Bucharest), 67, no.12, 2016, p. 2643

25.HUTCHINS GM, KESSLER-HANNA A, MOORE GW. Development of the coronary arteries in the embryonic human heart. Circulation. $1988 ; 77(6): 1250-1257$.

26. HUTCHINS GM, SILVERMAN KJ: Pathology of the stone heart syndrome: massive myocardial contraction band necrosis and widely patent coronary arteries. Am J Pathol 95: 745, 1979.

27.BONTE, D.C., BOGLUT, A., DUTA, C., PETRE, I., BERNAD, E.,VLAD DALIBORCA, C., IACOB, R.E., DIMA, M., IACOB, D., The Harmful Effects of Smoking during Pregnancy and Correlating Lead and Selenium Levels in Mothers and Premature Fetuses, Rev. Chim.(Bucharest), 67, no.1, 2016, p. 116

28.FEINSTEIN S. B., LANG R. M., DICK C. et al., Contrast echocardiography during coronary arteriography in humans: perfusion and anatomic studies, J Am Coll Cardiol, 1988, 1(1):59-65.

29. FUTAMI C, TANUMA K, TANUMA Y, SAITO T.The arterial blood supply of the conducting system in normal human hearts. Surg Radiol Anat. 2003 Apr;25(1):42-9.

30.WADA AM, WILLET SG, BADER D. Coronary vessel development: a unique form of vasculogenesis. Arterioscler Thromb Vasc Biol. 2003;23(12):2138-45.

31.TEVOSIAN SG, DECONINCK AE, TANAKA M, et al. FOG-2, a cofactor for GATA transcription factors, is essential for heart morphogenesis and development of coronary vessels from epicardium. Cell 2000;101:729-739.

32.KAWASHIMA T, SASAKI H.The morphological significance of the human sinuatrial nodal branch (artery). Heart Vessels. 2003;18(4):213219.

33.BERDAJS D, PATONAY L, TURINA MI (2003) The clinical anatomy of the sinus node artery. Ann.Thorac.Surg; 76(3):732-5.

34.BERNANKE DH, VELKEY JM. Development of the coronary blood supply: changing concepts and current ideas. Anat Rec. 2002;269:198208.

35.PETRESCU Cl, RUSU MC, NICULESCU MC, NICULESCU V. Studiul anatomic al arterei nodului sinoatrial. Infomedica 2006: 2(136); p2629.

36.PODOLEANU L, RUSU M, DIDILESCU A Muํochii papilari multipli ai ventriculului stang, Revista Romana de Anatomie functionala si clinica, macro- si microscopica si de Antropologie, 2, nr.4, 2003, p.99-101.

37.VOCI P., BILOTTA F., CARETTA Q. et al., Papillary muscle perfusion pattern. A hypothesis for ischemic papillary muscle dysfunction, Circulation, 1995, 91:1714-1718. 
38.TEVOSIAN SG, DECONINCK AE, TANAKA M, SCHINKE M, et al., FOG-2, a cofactor for GATA transcription factors, is essential for heart morphogenesis and development of coronary vessels from epicardium. Cell. 2000;101:729-739.

39.BERNAD, E., S., DUTA, C., BERNAD, S.I., PANTEA, S., PETRE, I., Investigation of Chorionic Artery Bifurcation Using Micro Vascular Casting Model, Rev. Chim..(Bucharest), 67, no.2, 2016, p. 339

40.TOMANEK RJ, ZHENG W, PETERS KG, LIN P, HOLIFIELDJS, SUVARNA $P R$. Multiple growth factors regulate coronary embryonic vasculogenesis. DevDyn. 2001;221:265-273.

41.VELKEY J M, BERNANKE DH. Apoptosis during coronary artery orifice development in the chick embryo. Anat Rec. 2001;262:310317.

42.BIELSCHOWSKY M, Eine Modifikation meines Silverimprägnationsverfahrens zur Darstellung der Neurofibrillen. J fur Psychologie Neurologie,1908, 12:135-137.
43.TOSHIKI U., Silver diagnosis in neuropathology: principles, practice and revised interpretation Acta Neuropathol. 2007 May; 113(5): 483499.

44.LITCHFIELD S, NAGY Z, New temperature modification makes the Bielschowsky silver stain reproducible. Acta Neuropathol (Berl), 2001, 101:17-21.

45.GHIBAN, N; BORTUN, C. M; BORDEASU, I; GHIBAN, B; FAUR, N; CERNESCU, A; HANGANUU SC; Evaluation of Mechanical Properties by Stereo-and Scanning Electron Microscopy of Some Heat Curing Dental Resins, Mat. Plast., 47, no. 2, 2010, p. 240

46.CAPLESCU, C.R., MARSAVINA, L., BORDEASU, I., SEKEI, R., The fracture of polyurethane materials in the presence of stress concentrators, Mat. Plast., 47, no. 2009, p.379

47.CRAINICEANU, Z., , IANES, E., MATUSZ, P., BLOANCA, V., SELEACU, E., NARAD, V., NARAD, G., NODITI G., BRATU, T., Method of Titanium Plate Use for Morphological and Functional Human Face Recontruction, Mat. Plast., 53, no. 3, 2016, p. 521

Manuscript received: 14.03 .2017 